\title{
SWOT Analysis on the Implementation of Online Learning During the Covid-19 Pandemic
}

\author{
Putri Dina Mardika ${ }^{1}, \mathrm{Nilma}^{2}$, Shinta Dwi Handayani ${ }^{3}$, Ega Shela Marsiani ${ }^{4}$ \\ \{putridinamar@gmail.com ${ }^{1}$, nilma23juli@gmail.com ${ }^{2}$, shintadh.1109@gmail.com ${ }^{3}$, \\ egashela@gmail.com ${ }^{4}$ \} \\ Universitas Indraprasta PGRI, Jakarta, Indonesia ${ }^{1234}$
}

\begin{abstract}
Since March 2020, the Covid-19 pandemic has spread to Indonesia. Education, like other areas of life, was seriously affected by the pandemic. Physical and social restrictions, which are the main means of preventing the spread of the virus, force adjustments in carrying out teaching and learning activities. The Indonesian Ministry of Education and Culture also issued a policy for all teaching and learning activities to be carried out from home, so that lecture activities must be carried out online using distance learning applications. In this study, SWOT analysis was used to identify various factors that influence online lectures, including the factors of strengths, weaknesses, opportunities, and threats. The results of the analysis indicate the need to adjust the mindset in learning, as well as collaboration between the government, universities, and the technology and telecommunication industry in administering online lectures.
\end{abstract}

Keywords: Online Lectures, Applications, SWOT Method, Covid-19

\section{Analisis SWOT terhadap Penerapan Kuliah Daring di Masa Pandemi Covid-19}

\begin{abstract}
Abstrak. Sejak Maret 2020, pandemi Covid-19 telah menjalar hingga ke Indonesia. Pendidikan, sebagaimana bidang-bidang kehidupan lain, mengalami dampak serius akibat pandemi tersebut. Pembatasan fisik dan sosial yang merupakan cara utama untuk mencegah penyebaran virus memaksa dilakukannya penyesuaian-penyesuaian dalam menyelenggarakan kegiatan belajar-mengajar. Kementrian Pendidikan dan Kebudayaan RI pun mengeluarkan kebijakan agar seluruh kegiatan belajar-mengajar dilakukan dari rumah, sehingga kegiatan perkuliahan harus dilakukan secara daring dengan menggunakan aplikasi pembelajaran jarak jauh. Dalam studi ini, analisis SWOT digunakan untuk mengidentifikasi faktor-faktor yang memengaruhi perkuliahan daring, mencakup faktor-faktor kekuatan, kelemahan, peluang, dan ancaman. Hasil analisis SWOT menunjukkan perlunya penyesuaian pola pikir dalam belajar, serta kolaborasi antara pemerintah, perguruan tinggi, dan industri teknologi dan telekomunikasi dalam penyelenggaraan perkuliahan daring.
\end{abstract}

Kata kunci: Kuliah Daring, Aplikasi, Metode SWOT, Covid-19 


\section{Pendahuluan}

Kasus pneumonia kali pertama dilaporkan di Wuhan, Provinsi Hubei, Republik Rakyat Tiongkok, pada Desember 2019. Belum dapat dipastikan penularan kasus ini, namun kasus pertama dihubungkan dengan pasar ikan di Wuhan. Awalnya, penyakit ini dinamakan sementara sebagai 2019 Novel Coronavirus (2019-nCoV), kemudian WHO mengumumkan nama baru pada 11 Februari 2020, yaitu Coronavirus Disease (COVID-19) yang disebabkan oleh virus Severe Acute Respiratory Syndrome Coronavirus-2 (SARS-CoV-2) [1]. Pada tanggal 2 Maret 2020, dua kasus pertama wabah Covid-19 terkonfirmasi di Indonesia [1]. Untuk mencegah penularan, WHO menyarankan untuk tidak berada di tempat berkumpulnya banyak orang, menggunakan masker ketika berada di luar rumah, selalu mencuci tangan, dan menjaga imunitas tubuh agar tetap sehat. Dapat dikatakan kunci pencegahan penularan Covid19 meliputi pemutusan rantai penularan dengan isolasi, deteksi dini, dan melakukan proteksi dasar [1]. Pendidikan menjadi salah satu dari banyak aspek kehidupan yang terdampak oleh penyebaran virus tersebut. Dunia pendidikan terpaksa harus mengubah haluan demi tetap berlangsungnya kegiatan belajar-mengajar; kegiatan yang sebelumnya dilaksanakan secara bertatap muka, kini harus tetap dilaksanakan secara jarak jauh. Kuliah daring dilaksanakan dengan menggunakan aplikasi yang terintegrasi dengan dukungan teknologi informasi.

Kementerian Pendidikan dan Kebudayaan Republik Indonesia (Kemendikbud) kemudian membuat kebijakan pendidikan dalam masa darurat penyebaran Covid-19. Berdasarkan kebijakan tersebut, proses belajar dilaksanakan di rumah melalui pembelajaran daring atau jarak jauh sesuai dengan kondisi masing-masing dengan meninjau kembali akses yang dapat dijangkau saat belajar dari rumah [2]. Kegiatan belajar di perguruan tinggi dilakukan dengan mengurangi pertemuan antara mahasiswa dengan mahasiswa lain, ataupun antara mahasiswa dengan dosen [3]. Kuliah daring menjadi pembicaraan hangat di tengah wabah Covid-19. Tak hanya di DKI Jakarta, hampir seluruh perguruan tinggi di Indonesia melakukan pembelajaran jarak jauh. Kegiatan belajar daring mengandalkan teknologi informasi dan berbagai macam gawai, seperti komputer, komputer jinjing, dan telepon pintar guna mengakses materi pelajaran dari mana pun [3]. Perkembangan beragam macam aplikasi yang dapat mendukung pelaksanaan kuliah daring pun mengalami percepatan, seperti aplikasi Google Classroom, Zoom Meeting, Whatsapp, Google Meet, dan lain sebagainya.

Tajuk "tetap di rumah, bekerja dari rumah, dan belajar dari rumah" (stay at home, work from home, and study from home) yang populer selama wabah Covid-19 semakin menonjolkan urgensi revolusi Industri 4.0, di mana semua aspek kehidupan, baik ekonomi, sosial, budaya, pendidikan, dan lainnya, lekat dengan karakteristik masyarakat digital. Untuk konteks di Indonesia, kondisi ini menjadi pelecut mengingat belum adanya kurikulum pendidikan yang menganut kegiatan belajar jarak jauh secara daring. Oleh karena itu, penting untuk meninjau kembali kesiapan atau kompetensi sumber daya, serta dukungan infrastruktur teknologi informasi, khususnya platform pembelajaran daring, dalam menyukseskan kegiatan belajar-mengajar jarak jauh.

\section{Metode}

Dalam studi ini, pengumpulan dan analisis data dilakukan dengan menggunakan metode "analisis isi deskriptif" (descriptive content analysis). Metode ini dimaksudkan untuk menggambarkan isi dari suatu informasi atau teks tertentu. Analisis dilakukan terhadap 
berbagai artikel ilmiah terkait pembelajaran dari selama masa pandemi Covid-19. Artikel ilmiah diperoleh dari jurnal internasional, nasional, dan berbagai sumber lain yang sejenis [4]. Data yang telah dihimpun kemudian dianalisis dengan menggunakan analisis SWOT. Dalam analisis, akan diidentifikasi berbagai faktor yang memengaruhi pembelajaran daring. Faktorfaktor tersebut kemudian dikelompokkan berdasarkan kategorisasi SWOT, terdiri atas kekuatan (strenght), kelemahan (weakness), peluang (Opportunity), dan ancaman (threat). Analisis SWOT biasa digunakan untuk menganalisis suatu kondisi di mana akan dibuat sebuah rencana untuk melakukan suatu program kerja [5].

\section{Hasil dan Pembahasan}

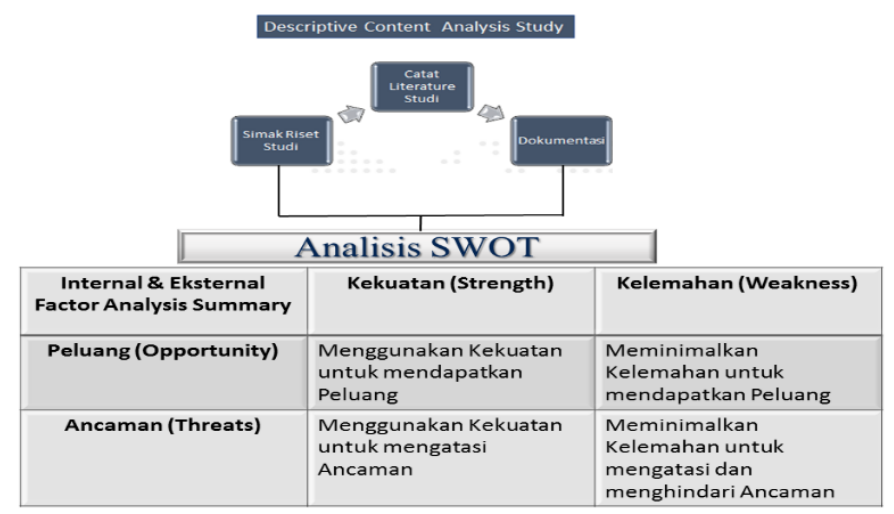

Gambar 1. Strategi Hasil SWOT

Berdasarkan data WHO, hingga 7 Juli 2020 Covid-19 telah ditetapkan sebagai pandemi global dengan 10.533.779 kasus positif yang terkonfirmasi di 215 negara di seluruh dunia. Covid-19 juga telah mewabah di Indonesia sejak awal Maret dan hingga tanggal 25 Oktober 2020 telah terdapat 389.712 kasus positif Covid-19-313.764 di antaranya telah dinyatakan sembuh, sementara 13.299 meninggal dunia [6].

Dampak pandemi Covid-19 telah mengubah secara drastis berbagai bidang kehidupan manusia. Di bidang pendidikan, kuliah daring menjadi solusi bagi permasalahan yang dihadapi dalam kegiatan belajar-mengajar. Kegiatan yang seharusnya dilaksanakan secara tatap muka di kampus antara dosen dan mahasiswa, kini berubah menjadi daring dengan mengandalkan jaringan internet dan fasilitasi berbagai aplikasi. Berbagai bentuk perantaraan teknologi, seperti situs internet (website), pesan cepat (instant messenger), media sosial (social media), dan sistem manajemen pembelajaran (learning management system) digunakan untuk mendukung pembelajaran jarak jauh. Dosen dan mahasiswa dari berbagai bidang keilmuan dituntut harus dapat menyesuaikan diri dan beradaptasi dengan kondisi ini.

Pemerintah berperan penting dalam pemetaan pembelajaran daring di tiap-tiap wilayah, terutama untuk persoalan-persoalan yang berkaitan dengan bantuan penyelenggaraan sistem kuliah daring. Teknologi pembelajaran jarak jauh menggunakan aplikasi masih minim di beberapa perguruan tinggi di Indonesia. Kerap kali hanya perguruan-perguruan tinggi di kotakota besar saja yang sudah dapat beradaptasi, karena adanya kemudahan memperoleh informasi. Dukungan pemerintah dalam merealisasikan pembelajaran jarak jauh antara lain 
diwujudkan dengan pemberian bantuan kuota internet gratis untuk dosen dan mahasiswa per bulan September hingga Desember 2020.

Menteri Pendidikan dan Kebudayaan Nadiem Makarim mengatakan bahwa kementrian yang dipimpinnya telah menyiapkan anggaran sebanyak Rp 7,2 triliun untuk subsidi kuota internet selama empat bulan. Kuota internet yang diperoleh dosen dan mahasiswa sebesar 50 GB. [7]. Berdasarkan data International Telecommunication Union (ITU) dan Badan Pusat

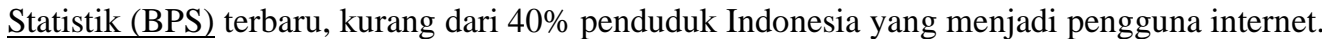
Hanya 3\% yang secara reguler mendapatkan akses internet dengan bandwidth cepat. Menurut data BPS pemakai telepon pintar hingga $100 \%$, namun hanya $20 \%$ masyarakat kita yang memiliki perangkat teknologi informasi [8].

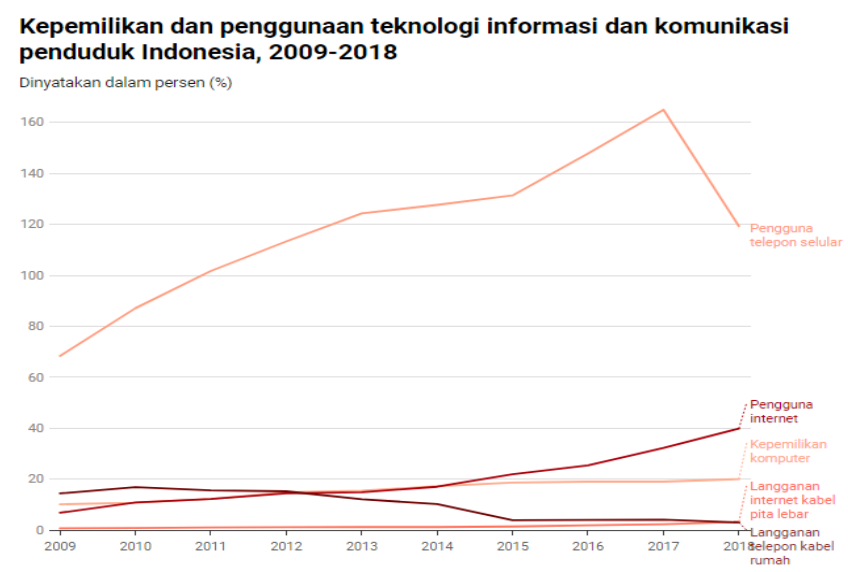

Gambar 2. Data International Telecommunication Union (ITU) dan Badan Pusat Statistik (BPS)

Sesuai dengan kerangka analisis SWOT, dalam pelaksanaan pembelajaran daring ini pun terdapat faktor-faktor internal yang dapat diidentifikasi sebagai kekuatan dan kelemahan. Serta faktor-faktor eksternal yang dapat diidentifikasi sebagai peluang dan ancaman. Berdasarkan temuan penelitian, keempat faktor tersebut dapat disajikan dalam bentuk matriks SWOT sebagai berikut:

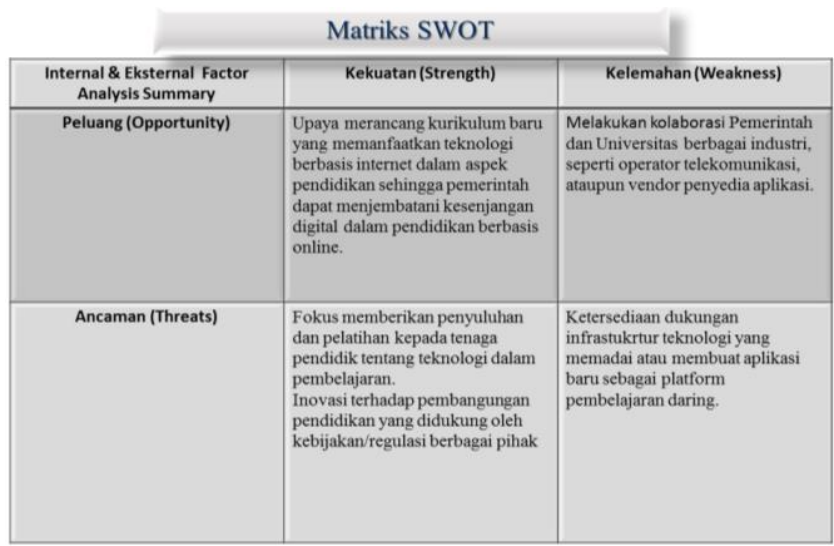

Gambar 2. Matriks SWOT 
Selanjutnya, akan dijelaskan lebih jauh hasil identifikasi faktor-faktor di atas. Kemudahan pembelajaran daring didukung oleh berbagai platform yang memfasilitasi beragam kegiatan, mulai dari diskusi hingga tatap muka secara virtual [4]. Belajar secara daring menggunakan aplikasi sangat penting agar dapat meningkatkan keinginan dan efektivitas serta memudahkan cara belajar [9]. Pembelajaran menggunakan aplikasi konferensi video membantu kegiatan belajar dan membuat mahasiswa mudah menerima materi [10]. Respons positif dari mahasiswa di antaranya menyebutkan bahwa metode kuliah daring ini memancing mahasiswa untuk lebih interaktif [3].

Perantaraan teknologi informasi memfasilitasi pembelajaran daring yang memungkinkan dosen dan mahasiswa berinteraksi dalam kelas virtual yang dapat diakses di mana saja dan kapan saja. Pembelajaran daring dapat membuat mahasiswa belajar mandiri dan meningkatkan motivasi mereka [11]. Basilaia, dkk. mengatakan bahwa apabila peralihan sistem pendidikan tradisional ke daring di sekolah telah berhasil, maka jam tambahan akan dapat digunakan untuk memeriksa tugas secara individu dan mengembalikan umpan balik, yang merupakan salah satu cara untuk meningkatkan keefektifan pengajaran kelompok. Siswa akan bekerja lebih mandiri. Hal ini dapat menjadi keuntungan karena memungkinkan siswa untuk mendapatkan keterampilan baru [12]. Di antara faktor-faktor yang menjadi kekuatan adalah pembelajaran daring tidak dibatasi ruang dan waktu, serta adanya fasilitas yang diberikan secara gratis oleh pemerintah untuk mengakses aplikasi pembelajaran. Kemendikbud telah menjalin kemitraan dengan berbagai platform pembelajaran daring seperti Smart Class, Ruangguru, Google Indonesia, dan lain sebagainya [13]. Efektivitas yang dimaksud di sini adalah efektivitas penggunaan waktu dan tempat, volume pengguna, serta penggunaan fasilitas (alat tulis, buku, dan lainnya) [14].

Faktor internal selanjutnya adalah kelemahan. Kendala yang kerap dialami selama pembelajaran daring di antaranya koneksi lambat dan komunikasi dosen tidak dimengerti oleh mahasiswa [15]. Kuliah daring melalui berbagai aplikasi seperti Zoom, Whatsapp, dan Google Classroom memiliki kesulitan masing-masing. Kuota internet menjadi boros ketika kuliah sering dilakukan melalui konferensi video, sehingga membutuhkan biaya yang cukup mahal. Sementara itu, interaksi cenderung kurang apabila kuliah hanya dilakukan melalui obrolan (chat) di Whatsapp ataupun Google Classroom [16].

Kelemahan lainnya adalah mahasiswa tidak terawasi dengan baik selama proses pembelajaran daring. Lemahnya sinyal internet dan mahalnya biaya kuota menjadi tantangan tersendiri pembelajaran daring [17]. Pembelajaran daring memiliki keterbatasan, karena tidak memungkinkan dosen untuk memantau secara langsung aktivitas mahasiswa selama perkuliahan. Mahasiswa juga kerap mengalami kendala dalam menerima dan mengerti materi perkuliahan, serta kurang interaktif selama pelaksanaan kelas daring [3]. Beberapa macam kendala yang menonjol dalam penggunaan aplikasi Zoom untuk perkuliahan daring ini, di antaranya jaringan internet yang buruk, pengeluaran kuota internet yang besar, dan ukuran aplikasi Zoom yang tergolong cukup besar untuk sebagian telepon genggam mahasiswa [14]. Kurangnya infrastruktur yang dipengaruhi oleh faktor ekonomi dan ketidaksiapan teknologi juga menjadi hambatan dalam pelaksanaan kegiatan belajar daring. Akibatnya, pemberian materi tidak sepenuhnya lancar [18]. Sebagian penelitian juga melaporkan bahwa tidak sedikit mahasiswa yang kesulitan dalam memahami materi perkuliahan yang diberikan secara daring. Siswa cenderung kurang aktif karena pembelajaran monoton, dan materi pembelajaran daring belum mudah dipahami [19].

Selanjutnya, terdapat faktor-faktor eksternal yang dapat dikategorikan sebagai peluang dan tantangan. Terkait peluang, Anggi Afriansyah, peneliti sosiologi pendidikan di Pusat Penelitian Kependudukan LIPI, menyebutkan bahwa akses menjadi kata kunci bagi 
optimalnya pembelajaran daring. Oleh karena itu, pemerintah perlu menjembatani kesenjangan digital dalam penyelenggaraan pendidikan berbasis daring. Pemerintah perlu membangun kerja sama dengan perguruan-perguruan tinggi yang ada di seluruh Indonesia untuk merancang regulasi bagi pengembangan sistem pendidikan jarak jauh, agar dosen ataupun tenaga pendidik di bidang apa pun menguasai teknologi pendidikan daring. Pemerintah juga perlu memberikan peluang kepada setiap penyedia layanan (provider) atau operator telekomunikasi untuk berkolaborasi dalam penyelenggaraan pendidikan daring.

Faktor eksternal selanjutnya adalah ancaman. Berdasarkan temuan banyak peneliti sebelumnya, kesulitan-kesulitan yang dialami dalam penyelenggaraan kuliah daring antara lain keterbatasan sumber daya manusia (sebagian dosen atau tenaga pendidik kurang tanggap dalam mengoperasikan aplikasi), kurangnya sosialisasi perihal aturan pembelajaran jarak jauh, keterlambatan mahasiswa dalam mengerti aplikasi yang digunakan untuk mengikuti perkuliahan daring, keterbatasan jaringan internet, hingga keterbatasan perangkat atau gawai yang digunakan karena adanya kesenjangan ekonomi di antara para mahasiswa. Kekhawatiran utama terletak pada kurangnya interaksi antara dosen dan mahasiswa, di mana dosen memberikan materi dan tugas tanpa ada umpan balik dari mahasiswa dikarenakan komunikasi yang terbatas hanya melalui aplikasi. Akibatnya, berisiko pada realisasi materi yang tidak tercapai, mengingat belum adanya kurikulum pendidikan di Indonesia yang menganut kegiatan belajar daring.

\section{Simpulan}

Berdasarkan hasil analisis SWOT mengenai penerapan kuliah daring di saat pandemi Covid-19, dapat ditarik beberapa rekomendasi yang potensial untuk meningkatkan kualitas penyelenggaraan pendidikan dengan metode daring. Pada tataran kognitif, perlu adanya penyesuaian pola pikir yang lebih terstruktur sehingga dapat beradaptasi terhadap cara baru dalam belajar-mengajar menggunakan aplikasi komputer. Perancangan kurikulum baru yang sesuai dengan kondisi saat ini dapat diupayakan oleh pemerintah dengan memanfaatkan kesempatan berkolaborasi dengan berbagai perguruan tinggi di Indonesia, industri teknologi pembelajaran, dan operator telekomunikasi. Penyuluhan dan pelatihan bagi tenaga pendidik tentang teknologi dalam pembelajaran agar memiliki keterampilan digital juga perlu dilakukan, di samping adanya dukungan regulasi. Ketersediaan infrastruktur yang memadai, dukungan sumber daya manusia, serta kebijakan dan regulasi yang tepat diharapkan akan dapat mengatasi berbagai kendala dalam penyelenggaraan pembelajaran daring. Dengan demikian, Indonesia akan lebih siap dalam menghadapi revolusi pendidikan berbasis daring.

\section{Referensi}

[1] Susilo A, Rumende CM, Pitoyo CW, Santoso WD, Yulianti M, Herikurniawan H, et al. Coronavirus Disease 2019: Tinjauan Literatur Terkini. Jurnal Penyakit Dalam Indonesia. 2020;7(1):45-67.

[2] Kementrian Pendidikan dan Kebudayaan. Surat Edaran Menteri Pendidikan dan Kebudayaan Nomor 4 Tahun 2020 mengenai Pelaksanaan Kebijakan Pendidikan Dalam Masa Darurat Penyebaran Corona Virus Disease (Covod-19). Jakarta: Kemendikbud.

[3] Firman F, Rahayu S. Pembelajaran Online di Tengah Pandemi Covid-19. I“, IJES: Indonesian Journal of Educational Science. 2020;2(2):81-9. 
[4] Herliandry LD, Nurhasanah N, Suban ME, Kuswanto H. Pembelajaran Pada Masa Pandemi Covid19. JTP - Jurnal Teknologo Pendidikan. 2020;22(1):65-70.

[5] Mardika PD. Analisis Strategi E-Business Pada Bandung Smart City. Jurnal Faktor Exacta. 2018;11(1):85.

[6] Gugus Tugas Percepatan Penanganan COVID-19 Indonesia, "Data COVID-19 Global dan Indonesia. Sumber: https://covid19.go.id/.

[7] Itjen Kemendikbud. Mencerdaskan Kehidupan Bangsa mengenai 27,3 juta Pendidik dan Siswa Terima Bantuan Kuota Internet. Sumber: https//itjen.kemdikbud.go.id/public/post/detail/273-jutapendidik-dan-siswa-terima-bantuan-kuota-internet:

[8] Triwibowo W. Gagap 3 aspek vital: kuliah online di tengah COVID-19 bisa perparah gap akses pembelajaran bermutu bagi mahasiswa miskin. THE CONVERSATION: Disiplin Ilmiah, Gaya Jurnalistik. Sumber: https//theconversation.com/gagap-3-aspek-vital-kuliah-online-di-tengahcovid-19-bisa-perparah-gap-akses-pembelajaran-bermutu-bagi-mahasiswa-miskin-134933

[9] Sasongko DB, Fatirul N, Hartono. Pengembangan E-Learning dengan Video Conference untuk Pendukung Pembelajaran Informatika Terapan di Politeknik Kelautan dan Perikanan Sidoarjo. Jurnal Education and Development. 2019;7(2):236-40.

[10] Ismawati D, Prasetyo I. Efektivitas Pembelajaran Menggunakan Video Zoom Cloud Meeting pada Anak Usia Dini Era Pandemi Covid-19. Jurnal Obsesi: Jurnal Pendidikan Anak Usia Dini 2020;5(1):665.

[11] Setiawan AR, Puspaningrum M, Umam K. Pembelajaran Daring di Tengah Wabah Covid-19. BIODIK: Jurnal Ilmiah Pendidikan Biologi. 2019;6(2):187-92.

[12] Basilaia G, Kvavadze D. Transition to Online Education in Schools during a SARS-CoV-2 Coronavirus (COVID-19) Pandemic in Georgia. Pedagogic Research. 2020;5(4).

[13] Abidah A, Hidaayatullaah HN, Simamora RM, Fehabutar D, Mutakinati L. The Impact of Covid19 to Indonesian Education and Its Relation to the Philosophy of "Merdeka Belajar." SiPoSE: Studies in Philosophy of Science and Education. 2020;1(1):38-49.

[14] Nur MR , Ilyas T, Yorita FL. Penggunaan Aplikasi Zoom Cloud Meetings Dalam Kuliah Statistik Pendidikan Di Fakultas Agama Islam Universitas Islam Malang. VICRATINA: Jurnal Pendidikan Islam. 2020;5(1):1-5.

[15] Astuti P, Febrian F. Blended Learning Syarah: Bagaimana Penerapan dan Persepsi Mahasiswa. Jurnal Gantang. 2019;4(2):111-9.

[16] Naserly MK. Implementasi Zoom, Google Classroom, Dan Whatsapp Group Dalam Mendukung Pembelajaran Daring (Online) Pada Mata Kuliah Bahasa Inggris Lanjut. Jurnal Aksara Publik. 2020;4(2):155-65.

[17] Afriansyah A. Covid-19, Transformasi Pendidikan dan Berbagai Problemnya. Artikel Online Pusat Penelitian Kependudukan LIPI, Jilid 24, April. 2020. (Diakses pada laman https://kependudukan.lipi.go.id/id/berita/53-mencatatcovid19/838-covid-19-transformasipendidikan-dan-berbagai-problemnya pada 23 Oktober 2020)

[18] Briliannur Dwi C, Aisyah Amelia, Uswatun Hasanah, Abdy Mahesha Putra HR, Universitas. Analisis Keefektifan Pembelajaran Online di Masa Pandemi Covid-19 Briliannur. MAHAGURU: Jurnal Pendidikan Guru Sekolah Dasar. 2020;2(1):28-37.

[19] A. Sadikin \& N. Hakim. Pengembangan Media E-Learning Interaktif Dalam Menyongsong Revolusi Industri 4.0 Pada Materi Ekosistem Untuk Siswa SMA Biodik: Jurnal Ilmu Pendidikan Biologi. 2019;5(2):131-8A. 